\title{
Understanding the Possible Impact of Exotic Parrots on Human Health and Well Being
}

\author{
Esra PER \\ Department of Biology, Faculty of Science, Gazi University, Teknikokullar, Ankara, Turkey
}

How to cite: Per, E. (2021). Understanding the Possible Impact of Exotic Parrots on Human Health and Well Being. J. Anatolian Env. and Anim. Sciences, 6(3), 288-293.

Atıf yapmak için: Per, E. (2021). Egzotik Papağanların İnsan Sağlığı ve Refahı Üzerindeki Olası Etkisini Anlamak. Anadolu Çev. ve Hay. Dergisi, 6(3), 288293.

Abstract: Parrots are birds that live in the tropical and subtropical regions of the world. The international trade of parrots is carried out according to the CITES Convention. A total of 135 parrot species were imported and 40 parrot species were re-exported between 1982 and 2016 in Turkey. The introduction and establishment of alien species in any country is an undesirable situation. Alien species can have a negative impact on ecosystem, economic, human health and social factors in countries. Therefore, alien species should be monitored. In this study, the possible impact of exotic parrots on human health and well-being is assessed, which was given in three stages (literature search, bird watching database, ectoparasite investigation). Cage birds (pets) were the subject of $89 \%$ of theses, $88 \%$ of WoS articles, and $92 \%$ of Dergipark articles, according to the results. There have been several records of the sounds of the alien rose-ringed parakeet (Psittacula krameri) (RRP) and the Alexandrine parakeet (Psittacula eupatria) (AP) having

*Corresponding author's: Esra PER

Department of Biology, Faculty of Science, Gazi University, Teknikokullar, Ankara, Turkey esraper@gazi.edu.tr 凶: esraper@gazi.edu.tr negative impacts on human well-being. Both species have had no impact on human health to date in Turkey, but it is possible that in the future it could be determined that they carry various microorganisms and vectors. RRP and AP individuals live in the wild as a result of intentional or accidental introductions. Besides, pet trade on these species continues in Turkey. This situation poses a biosecurity concern. To overcome these issues, biosecurity measures should be increased in Turkey and incorrect scientific researches should not be considered in the management of these species.

Keywords: Alien species, biosecurity, incorrect assessment, public health, trade.

\section{Egzotik Papağanların İnsan Sağlığı ve Refahı Üzerindeki Olası Etkisini Anlamak}

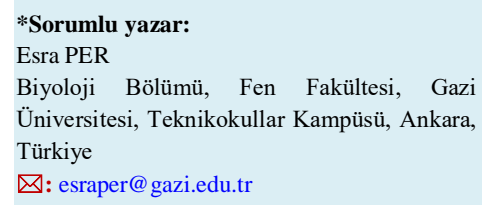

\begin{abstract}
Öz: Papağanlar, dünyanın tropikal ve subtropikal bölgelerinde yayılış gösteren kuşlardır. Uluslararası papağan ticareti CITES Sözleşmesine bağlı olarak yapılmaktadır. Türkiye'de 1982 2016 y1lları arasında toplam 135 papağan türü ithal edilmiş ve 40 papağan türü yeniden ihraç edilmiştir. Yabancı türlerin ülkeye girişi ve yerleşmesi istenmeyen bir durumdur. Yabancı türlerin ülkelerdeki ekosistem, ekonomi, insan sağlığı ve sosyal faktörler üzerinde olumsuz etkileri olabilmektedir. $\mathrm{Bu}$ nedenle yabancı türler izlenmelidir. $\mathrm{Bu}$ çalışmada Türkiye'de egzotik papağanların insan sağlığı ve refahı üzerindeki olası etkisi değerlendirilmiştir. Araştırma üç aşamalı olarak planlanmıştır (literatür araştırması, kuş gözlem veri tabanı ile ektoparazit araştırması). Tezlerin \% 89'unun, WoS makalelerinin \% 88'inin ve Dergipark makalelerinin \% 92'sinin kafes kuşları (evcil hayvanlar) üzerine olduğu tespit edildi. Yeşil papağan (Psittacula krameri) (YP) ve İskender papağanı (Psittacula eupatria) (IP)'nın seslerinin insan refahı üzerinde olumsuz etkileri olduğuna dair birkaç kayıt vardır. Her iki tür de Türkiye'de şimdiye kadar insan sağlığı üzerinde herhangi bir etkiye sahip değildir, ancak gelecekte bu türlerin çeşitli mikroorganizmaları ve vektörleri taşıdığı tespit edilebilir. YP ve IP, kasıtlı veya kazara bırakılmalarının bir sonucu olarak vahşi doğada yaşıyor. Ayrıca Türkiye'de bu türlerin evcil hayvan ticareti devam etmektedir. Bu durum biyogüvenlik açısından endişe oluşturmaktadır. Bu konuların üstesinden gelmek için Türkiye'de biyogüvenlik önlemleri artırılmalı ve bu türlerin yönetiminde yanlış bilimsel araştırmalar dikkate alınmamalıdır.
\end{abstract}

Anahtar kelimeler: Biyogüvenlik, halk sağlığı, ticaret, yabancı türler, yanlıș değerlendirme. 


\section{INTRODUCTION}

People have been transporting parrots to various countries around the world since the 1400s. A total of 44 species have established new populations outside of their native ranges (Runde et al., 2007). The spread of nonnative species was facilitated by the globalization of trade and travel. Some of these species have been established out of the native range and cause serious environmental, economic and human health effects (Keller et al., 2011).

Parrots are birds that locate in tropical and subtropical regions throughout the world. The international trade of parrots is carried out according to the CITES Convention. According to the CITES database, 135 parrot species were imported and 40 parrot species were reexported in Turkey between 1982 and 2016 (Per, 2018). The Alexandrine parakeet (Psittacula eupatria) (AP) was first recorded in Ankara in 1990, and the rose-ringed parakeet (Psittacula krameri) (RRP) was first recorded in Ankara in 1975 (Per, 2019). These species have spread and established breeding populations in the wild in Turkey (Kirwan et al., 2008). The introduction and establishment of alien species in a country is an undesirable circumstance since alien species can have an adverse impact on a country's environment, culture, human health, and social factors. In order to make an accurate assessment, monitoring is required. Therefore, the Parakeet Census of Turkey study has been conducted since 2016 .

The introduction of alien species by humans, for different reasons, has resulted in the introduction of more species into the local environment. The low level of quarantine measures and border controls are major issues in this field. For economic interests, many alien species have been deliberately introduced. Invasive alien species have different effects on people (Mcneely, 2001). Parrots can carry potential disease vectors, and threaten not only native bird species but also cage birds, poultry flocks, aviculture and human health (Runde et al., 2007). An impact evidence-mapping database on the ecological and social impacts of 11 non-native parrot species in Europe has been created. This database primarily focuses on two species: RRP (64\%) and Monk parakeet (Myiopsitta monachus) (19\%). Parrots have impacts on human health (5\%) and human well-being $(3 \%)$ based on this database (White et al., 2019). The issue of human health and human well-being in the management of introduced parrot species is included in the socio-economic assessment.

Through enhanced international cooperation, the Convention on Biological Diversity provides significant opportunities for addressing the complex global challenges of Invasive Alien Species (IAS) (Mcneely, 2001). Alien species are considered to be a threat to overall biodiversity loss worldwide (Bremner \& Park, 2007). An important but often overlooked form of impact of native species is the parasite-mediated one. The alien species can carry parasites from their native distribution areas or receive parasites from native species, potentially raising the risk of parasite transmission and spread. The identification of parasites carried by alien species is crucial for determining and potentially avoiding negative effects (Mori et al., 2015). There is not any general assessment of invasive alien parakeet species and ectoparasites in the wild, Turkey.

As a result of improvements in Citizen Science, it is possible to effectively monitor IAS through community engagement (Roy et al., 2018). Invasion biology focuses on ecological effects by estimating the spread and developing control methods rather than documenting the economic and social impact on society. The next generation IAS science and policy should reflect the fact that IAS are becoming a major driver of global environmental change with implications for biodiversity and human welfare (Pejchar \& Mooney, 2009). Public support can be critical to the success of management projects. Education activities can help raise public awareness and support (Bremner \& Park, 2007). The Ministry of Agriculture and Forestry has begun to work for the management of IAS in marine and coastal ecosystems in Turkey. The new management approaches for terrestrial IAS will be developed by the ministry in the coming years.

The aim of this study is to understand the possible impact of exotic parrots on human health and well-being, as well as to evaluate current research and make recommendations for future studies.

\section{MATERIALS AND METHODS}

This research was carried out in three stages. A literature search was conducted in the first stage to determine the impact of parakeets and parrots on public health in Turkey, and a parrot research database was created by using Web of Science (WoS), the digital platform of academic journals published in Turkey (Dergipark), and theses. The database queries were used to make the numerical assessment.

For this database, the WoS and Dergipark systems were searched based on studies conducted in Turkey. The species in this database have been subjected to numerical assessments and comparisons. The following parameters were used to conduct database queries: "bird", "aves", "parrot", "parakeet", "parasite”, "bacteria", "virus", "impact", and "human health" for the research method; "article", "guide", "book" and "project report" for the research type; "year" for the completion date. 
The National Thesis Centre of the Turkish Council of Higher Education CoHE database was searched for master's theses and doctoral dissertations (Yöktez, 2019). The following parameters were used to conduct database queries: "bird", "aves", "parrot", "parakeet", "parasite", "bacteria", "virus", "impact", and "human health".

In the second stage, "The Turkey Parakeet Census Voluntary Network" was established in 2016. For RRP and AP observations, a Google Docs observation form was developed. Observers sent their different parrot observations by observation form. A database was established for exotic parrot monitoring in Turkey. This database includes information on parrots' impacts on the ecosystem, economy (as an agricultural pest), and social factors (disease and sound) (The Parakeet Census of Turkey, 2019). The observation results were used to make numerical assessment.

With the permission of the Ministry of National Defence, fieldwork was conducted in the Anttkabir Campus (Memorial Tomb) (3955'33"N 32 50'10"E), Ankara province, Central Anatolia. Anttkabir is made up of the monumental blog containing the mausoleum and the Peace Park. Peace Park formed by 104 different species of plants, shrubs, and trees sent from different parts of Turkey and various countries of the world (Afghanistan, Austria, Belgium, Canada, China, Cyprus, Denmark, Egypt, Finland, France, Germany, Greece, India, Iraq, Israel, Italy, Japan, Norway, Portugal, Spain, Sweden, United Kingdom, United States and Yugoslavia) is a symbolic League of Nations (Culture and Tourism Directorate of Ankara, 2013). This campus is open to the public every day from 9:00 a.m. to 5:00 p.m. (17:00, till 4:00 p.m./16:00 in winter).

The RRP population was observed for a year and feathers were collected in Anttkabir Campus for the third stage. Ectoparasite research was carried out in and around the mausoleum. The mausoleum building is home to RRP individuals (Figure 1).

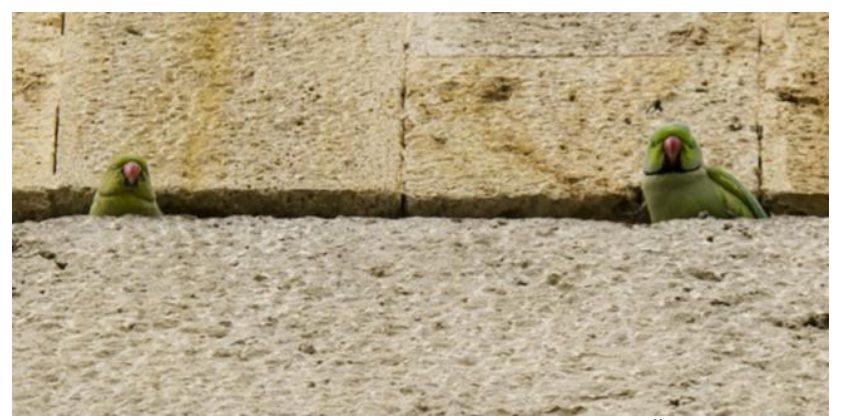

Figure 1. RRP nest on the mausoleum building (C) Ömer Çetin.

The Featherbase template is used to identify bird feathers (Featherbase, 2019). Parakeets breeding on the mausoleum building had their contour feathers, flight, and tail feathers collected. In the mornings, parakeets are very active around their nests on the mausoleum building. Meanwhile, some of their feathers fell out when they entered and exited the nest. As soon as the feathers hit the ground, they were quickly gathered. Each bird feather was examined for ectoparasites. Each sample was first examined in a petri dish using an Olympus SZX7 stereo microscope at Gazi University, imaging procedures on the samples. In the current study, a total of 35 feathers (wing, tail, and body contour) (Figure 2; Figure 3) were deposited.

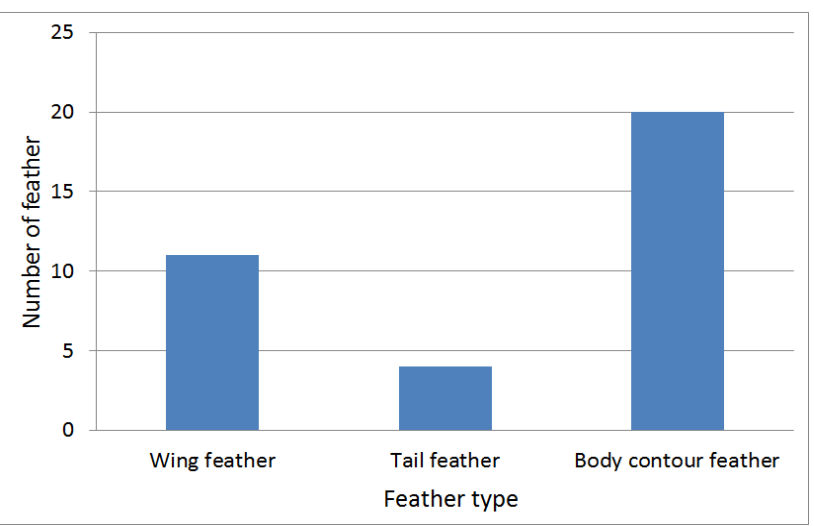

Figure 2. The ectoparasite examinations on feathers.
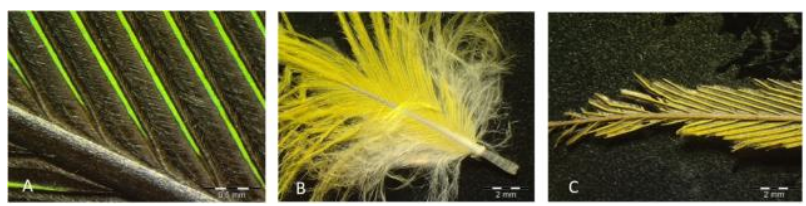

Figure 3. A-Flight feather, B-Body contour feather, C-Tail feather

\section{RESULTS AND DISCUSSION}

Alien parrots have ecological and social impacts in Europe and these effects are increasing (White et al., 2019). The number of exotic parrot species and their distribution areas are increasing in Turkey. The Citizen Science is used to monitor their ecological, economic, and cultural impacts (Per, 2019). The parrot research database was examined. The CoHE thesis database, WoS and Dergipark were assessed. Investigation of the publications on this subject revealed that $89 \%$ of theses, $88 \%$ of WoS articles and $92 \%$ of Dergipark articles are on cage birds (pets) (Table 1). There is no research on the impact of wild parakeets and parrots on human health and parasite interactions. All of the research on this subject has focused on cage birds.

Table1. The scientific database queries

\begin{tabular}{lcccccc}
\hline Researches & CoHE thesis database & $\%$ & WoS & $\%$ & Dergipark & $\%$ \\
\hline Breeding parakeet & 1 & 11 & 2 & 12 & 2 & 8 \\
Parrot as a pet & 8 & 89 & 15 & 88 & 24 & 92 \\
Total & 9 & 100 & 17 & 100 & 26 & 100 \\
\hline
\end{tabular}


According to the Parakeet Census of Turkey database, there are 247 AP observation records (in 19 provinces) and 2,265 RRP observation records (in 31 provinces) in and around urban areas. In Turkey, there are an estimated 2,000 RRP and 3,000 AP individuals. AP has established breeding populations in İstanbul. The breeding population of AP has increased dramatically in recent years in İstanbul. Provinces where RRP individuals have been observed; Adana, Adapazarı, Afyon, Ankara, Antalya, Balıkesir, Bolu, Burdur, Bursa, Çanakkale, Denizli, Gaziantep, Giresun, Eskişehir, Hatay, İstanbul, İzmir, Kastamonu, Kayseri, Kırşehir, Kocaeli, Manisa, Malatya, Mersin Muğla, Nevşehir, Osmaniye Samsun, Sinop, Şanlıurfa, Tekirdağ, Yalova. RRP has established breeding populations in ten provinces; İstanbul, İzmir, Ankara, Yalova, Antalya, Şanlıurfa, Eskişehir, Hatay, Adapazarı and Bursa.

There is no data on the ecological, economic, or social impact in $90 \%$ of the observation records. RRP individuals interact with Caucasian squirrel (Sciurus anomalus), common Buzzard (Buteo buteo), common myna (Acridotheres tristis), Eurasian magpie (Pica pica), hooded crow (Corvus cornix), jackdaw (Coloeus monedula), stray cat (Felis catus) and yellow-legged gull (Larus michahellis), while AP interacts with common myna, hooded crow and yellow-legged gull. The hybridization of AP and RRP individuals was not detected (impacts on the ecosystem). AP and RRP are widely spread in urban areas. So far, it hasn't been seen in rural areas, orchards and agricultural fields (no economic impact). There have been several observations of negative impact of both species due to their sounds (human well-being) in İstanbul's parks and gardens, where they roost in large flocks (social impact). Some observation records have been determined about AP and RRP individuals that have been illegally captured by humans.

The Anitkabir campus is home to a wide variety of native and non-native tree species (Culture and Tourism Directorate of Ankara, 2013). This campus provides a shelter for parakeets, who feed on the fruits and seeds of the trees during the year.

The biggest breeding parakeet population of Ankara was established in Anitkabir Campus (The Parakeet Census of Turkey, 2019). RRP individuals in Anitkabir have been observed for a year. Their population reached 50 individuals in the winter season, while nine pairs were observed during the breeding season. Their nests are located on the top of the mausoleum building. The height of the Mausoleum building where they establish their nests are 17 meters (Figure 1). The feathers of the RRP individuals were collected from here every morning. Stereo microscopy was used to examine feather samples, but no ectoparasites were detected. Individuals of the
Common swift (Apus apus) and RRP are both nesting in the same holes on the mausoleum building. However, feathers of common swift individuals were not found in the research field. As a result, It was impossible to determine whether common swifts nesting in this area has ectoparasites or not.

Ectoparasites can cause holes and structural problems on bird feathers (Per \& Aktaş, 2019). There were no structural problems observed on any of the 35 feathers examined (flight (11), tail (4), and body contour (20)) (Figure 3 A - B). Only the wear and tear at the ends of the tail feathers of the parakeets were observed (Figure $3 \mathrm{C}$ ). They build their nests on the mausoleum building's narrow holes. It's possible that their feathers were broken when they entered and exited the nests. Three of the Mausoleum's facades are home to parakeets. The 35 feathers examined were collected from these three sites, but it's unclear how many parakeets they belonged to.

According to the first data on the macroparasite fauna of alien parrots in Italy, seven RRP individuals were infested by ectoparasites. Four ectoparasite species were identified by examining thirty-one arthropod individuals; Neopsittaconirmus lybartota is one of them, with a native range in India. The other three arthropod species (Tarsopsylla o. octodecimdentata, Argas reflexus, and Laemobothrion cf. maximum) are common and native to Italy (Mori et al., 2015). Some ectoparasites are carried by birds (feather mite, lice, tick, and bed bug). Feather mites live on the bird's skin, within the quill, down and contour feathers, flight feathers, and tail feathers, in four different microhabitats (Gaud \& Atyeo, 1996). The feather collection is a good tool for studying feather mites, but parakeet individuals should be examined in detail for all ectoparasite groups. Ectoparasites carried by parakeets can be determined in the coming years by using the catching, marking, and releasing technique.

Parrot fever (Psittacosis ornithosis) disease is caused by bacteria called Chlamydophila psittaci. Many birds, especially parrots carry this bacteria species as a microparasite (Atay et al., 2012). RRP and AP individuals do not have any impact on human health until now in Turkey, but various microorganisms and vectors may be carried with alien parakeet species in the next years. There is a need for more research on this subject. However, for proper planning and interpretation of these studies, multidisciplinary studies in biology, veterinary, and public health are needed.

Psittacosis, salmonellosis, avian influenza, Newcastle's disease avian malaria, pasteurellosis, erysipelas, and tuberculosis are diseases that can be transmitted by parrots to humans or other birds (Runde et al., 2007). Introduced birds may act as a large reservoir for parasitic infections. They have the potential to spread 
parasites to other native species (Eguchi \& Amano, 2004). There is no data on this issue in Turkey. Parasitic examinations on parakeet individuals who are spreading in the wild and brought to veterinary faculties should be done and also blood samples should be taken. These samples can be used to detect internal parasites and ectoparasites of the parakeets which are distributed in the wild in Turkey.

There is no observation, evidence, or literature to indicate that two alien parakeet species (AP and RRP) have a negative impact on human health in Turkey. However, a presentation at the ESENIAS Conference was based on the incorrect assumption that these animals have a negative impact on human health (Oymak et al., 2017). These species carry risks with regard to human health in Turkey according to Oymak et al., 2017, but this is not correct since the wrong literature review and incorrect assessment were made with two articles. The species of parrot was not mentioned in the first article which was used as the literature (Tantaş et al., 1987). In the second article, a species of bacteria found on the grey parrot (Psittacus erithacus) was investigated (Tantaş et al., 1990). The word "parrot" is used in some articles about pet parrots in Turkey. The name of the parrot species is not written specifically, which is a lack of knowledge. In this research area, veterinarians should collaborate with ornithologists to identify species. According to scientific publications, AP and RRP species do not carry parasites as pets. Before this research, no preliminary study has been conducted in Turkey on ectoparasites carried by parakeets in the wild.

There are some observations about AP and RRP individuals that have been illegally captured by humans from breeding populations from time to time in Ankara, İstanbul and İzmir city centres (Per, 2019). Captured birds have the potential to get involved in the illicit trade cycle. Biosecurity measures should be increased regarding Invasive Alien Species in Turkey.

Nationwide controls and import bans are important measures to control the population growth of these alien species as well as limiting the spread of diseases (Stafford, 2003). To avoid the spread of diseases, the importation of wild birds from other countries into EU countries was banned in 2007 (Commission Decision, 2007). Prior to this ban, the deadly Newcastle disease entered Italy during shipment of parrots and finches imported from Pakistan in 2004. As a result of this incident, 4,000 birds were culled (World Parrot Trust, 2004). As a result of intentional or accidental introductions, RRP and AP now exist in the wild. The Republic of Turkey Ministry of Agriculture and Forestry banned rose-ringed parakeet imports in 2021, although the national trade of RRP individuals imported by Turkey in previous years will continue for some time. There is no import ban for AP in
Turkey. In terms of biosecurity, this is a concern and some significant changes are required.

A new strategy should be developed for exotic parrots in Turkey. The trade of species that have established a breeding population should be banned in order to prevent their distribution from expanding further in the country. In the parrot trade, Turkey should implement quotas and restrictions based on some parrot species in the parrot trade. For illegally traded animals, a risk assessment should be done (Per, 2018). The risk analysis should be done for Invasive Alien Species based on their ecosystem, economic and social impact in Turkey.

This study provides the following insights for future research: firstly, Biosecurity measures should be increased in Turkey. Secondly, the management of these species should not be based on incorrect scientific studies. Thirdly, a risk analysis of the potential socio-economic impacts of parrots should be performed, and a monitoring report should be prepared based on the results of the risk analysis. Also, there is a need for non-profit citizen science research to increase public awareness on this issue. Finally, The development of new interdisciplinary studies in the fields of public health and ecology would help in the prevention of the introduction of invasive alien species to new areas and the providing of rapid management responses.

\section{ACKNOWLEDGEMENTS}

I am grateful to all birdwatchers and citizens who contributed to the Parakeet Census of Turkey by sharing their observations. The present research's third stage was carried out with the permission of the Ministry of National Defence and the help of Cemalettin Erdoğan and Kasım Teke in Anitkabir Campus. The Rose-ringed parakeet photo was taken by Ömer Çetin. Stereo microscopy studies were carried out with the help of Zekiye Suludere and Damla Amutkan at Gazi University.

* Part of this study was presented and published as an abstract in the Joint ESENIAS and DIAS Scientific Conference and 9th ESENIAS Workshop held on 3 - 6 September 2019, Ohrid, Republic of North Macedonia.

\section{REFERENCES}

Atay, H., Tüvan, A., Demir, Ö. \& Balta, İ. (2012). $\dot{I} k l i m$ değişikliğinin sağllk üzerine etkileri. Meteoroloji İşleri Genel Müdürlüğü Araştırma Dairesi Başkanlığı Klimatoloji Şube Müdürlüğü. Orman ve Su İşleri Bakanlığı. Ankara, Turkey.

Bremner, A. \& Park, K. (2007). Public attitudes to the management of invasive non-native species in Scotland. Biological Conservation, 139, 306-314. DOI: 10.1016/j.biocon.2007.07.005 
Clayton, D.H. \& Walther, B.A. (1997). Collection and quantification of arthropod parasites of birds, In: Clayton, D.H., Moore, J. (Ed.), Host-parasite evolution: general principles and avian models,.), Oxford University Press, Oxford, UK.

Commission Regulation, (2007). Commission regulation (EC) No 318/2007 of 23 March 2007 laying down animal health conditions for imports of certain birds into the community and the quarantine conditions thereof. Official Journal of European Union, 84, 7-29.

Culture and Tourism Directorate of Ankara. (2013). Ankara, the Capital City of Turkish Republic where the cultures blended. Regional Directorate of Culture and Tourism. Ankara, Turkey.

Eguchi, K. \& Amano, H.E. (2004). Invasive birds in Japan. Global Environmental Research, 8, 29-39.

Featherbase. (2019). The Online library for bird feathers. Ring-necked Parakeet, https://www.featherbase.info/uk/species/Psittacul a/krameri (21.02.2019).

Gaud, J.W. \& Atyeo, W.T. (1996). Feather mites of the world Acarina, Astigmata: the supraspecific taxa. Annales du Musée Royal de l'Afrique Centrale Sciences Zoologiques, 277(1), 1-193, (2), 1-436.

Keller, R.P., Geist, J., Jeschke, J.M. \& Kühn, I. (2011). Invasive species in Europe: ecology, status, and policy. Environ Sci Eur, 23, 23. DOI: 10.1186/2190-4715-23-23

Kirwan, G.M., Boyla, K.A., Castell, P., Demirci, B., Özen, M., Welch, H. \& Marlow, T. (2008). The birds of Turkey: a study of the distribution, taxonomy and breeding of Turkish Birds, Christopher Helm, London.

Mcneely, J.A. (2001). The Great reshuffling - human dimensions of Invasive Alien Species. IUCN, Gland, Switzerland and Cambridge.

Mori, E., Ancillotto, L., Groombridge, J., Howard, T., Smith, V.S. \& Menchetti, M. (2015). Macroparasites of introduced parakeets in Italy: a possible role for parasite-mediated competition. Parasitology Research, 1149, 3277-3281. DOI: 10.1007/s00436-015-4548-2

Oymak, S., Büyük, B., Coban, H. \& Otkun, M. (2017). Settlement and reproduction of parrots in Istanbul and health implications. $7^{\text {th }}$ ESENIAS Workshop and Conference, Bulgaria, Sofia, 28-30 March 2017, 75 p.

Pejchar, L. \& Mooney, H.A. (2009). Invasive Species, Ecosystem Services and Human Well-Being. Trends in Ecology Evolution, 24, 497-504. DOI: 10.1016/j.tree.2009.03.016

Per, E., \& Aktaş, M. (2019). Tüy Akarı Araştırmalarında Farklı Örnek Toplama Metotlarının Bazı Ötücü Kuş Türlerine Uygulanması ve İzlenmesi. Commagene Journal of Biology, 3(2), 68-74. DOI: 10.31594/commagene.595924

Per, E. (2019). İnternet temelli araçların egzotik papağanların izlenmesine katkısı. Turkish Journal of Forestry, 20(4), 466-473. DOI: 10.18182/tjf.603520
Per, E. (2018). Tropikal ormanlardan Türkiye'ye papağan ticaretinin durumu. Turkish Journal of Forestry, 19(3), 275-283. DOI: 10.18182/tjf.450007

Roy, H., Groom, Q., Adriaens, T., Agnello, G., Antic, M., Archambeau, A.-S., Bacher, S., Bonn,A., Brown, P., Brundu, G., López, B., Cleary, M., Cogălniceanu, D., de Groot, M., DeSousa, T., Deidun, A., Essl, F., Fišer Pečnikar,Ž., Gazda, A., Gervasini, E., Glavendekic,M., Gigot, G., Jelaska, S., Jeschke, J., Kaminski, D., Karachle, P., Komives, T., Lapin, K.,Lucy, F., Marchante, E., Marisavljevic, D., Marja, R., Martín Torrijos, L., Martinou, A.,Matosevic, D., Mifsud, C., Motiejūnaitė, J., Ojaveer, H., Pasalic, N., Pekárik, L., Per, E.,Pergl, J., Pesic, V., Pocock, M., Reino, L., Ries, C., Rozylowicz, L., Schade, S.,Sigurdsson, S., Steinitz, O., Stern, N., Teofilovski, A., Thorsson, J., Tomov, R., Tricarico,E., Trichkova, T., Tsiamis, K., van Valkenburg, J., Vella, N., Verbrugge, L., Vétek, G.,Villaverde, C., Witzell, J., Zenetos, A., Cardoso, A.C., (2018). Increasing understandingof alien species through citizen science (Alien-CSI). Research Ideas and Outcomes, 4, DOI: 10.3897/rio.4.e31412

Runde, D.E., Pitt, W.C. \& Foster, J.T. (2007). Population ecology and some potential impacts of emerging populations of exotic parrots. Managing vertebrate invasive species. 42.

Stafford, T. (2003). Pest risk assessment for the monk parakeet in Oregon. Natural Resource Specialist 1, Oregon Department of Agriculture, Oregon.

Tantaş, A., Ak, S. \& Özgür, Y. (1990). Papağanlarda Candidiasis'te Etiolojik ve Terapotik Bulgular ve Kriterler Üzerine Çalışmalar, Ist. Ünv. Vet. Fak. Derg. 162, 181-184. Turkish

Tantaş, A., Ak, S. \& Yılmaz, H. (1987). Papağanlarda karşılaşılan bir S. Typhimurium olgusu. İstanbul Üniv. Vet. Fak. Derg. 131, 51-54.

The Parakeet Census of Turkey. (2019). http://trpapagansayimlari.blogspot.com/ (10.06.2019).

White, R.L., Strubbe, D, Dallimer, M, Davies, Z.G., Davis, A.J.S., Edelaar, P., Groombridge, J., Jackson, H.A., Menchetti, M., Mori, E., Nikolov, B.P., Pârâu, L.G., Pečnikar Živa, F., Pett, T.J., Reino, L., Tollington, S., Turbé, A. \& Shwartz, A. (2019). Assessing the ecological and societal impacts of alien parrots in Europe using a transparent and inclusive evidencemapping scheme. NeoBiota, 48, 45-69.

World Parrot Trust. (2004). Deadly Newcastle disease discovered in parrots and other birds imported from Pakistan to Italy. https://www.parrots.org/pdfs/our_\%20publicatio ns/psittascene/2004/04May59.pdf (11.07.2019).

Yöktez. (2019). The database of the Council of Higher Education (CoHE) National Thesis Center Database. https://tez.yok.gov.tr/UlusalTezMerkezi (01.06.2019). 